\title{
Changes in the freshwater balance of the Arctic during global warming analysis of the current state of research
}

\section{Introduction}

The modern Arctic is becoming warmer and more humid, the Arctic Ocean is increasingly free of ice in summer, and the thickness of ice decreases. In 2012, the absolute minimum of the September sea ice area was recorded, and in 2016 the lowest winter maximum of the area. The beginning of ice formation is shifted to a later date, the melting of snow and ice begins all earlier, the duration of the occurrence of snow cover is reduced. Extrapolation of observations of sea ice and air temperature indicates a possible release Arctic from the ice in the summer 2030-2040s. It is believed that the anthropogenic $\mathrm{CO}^{2}$ increase in the atmosphere is the main cause of modern warming which lead to feedbacks in the Arctic, increasing Arctic warming. The main influence is attributed to the decrease albedo. At the same time, the observed increase in the water vapor content in the atmosphere of the Arctic increases the influx of downward long-wave radiation to the surface of snow and ice, slowing down the winter buildup of ice and accelerating the summer melting of snow and ice. The source of the increase in the water vapor content in the arctic atmosphere is the atmospheric branch of the hydrological cycle, including moisture transport from low latitudes and inflow from the ocean surface.

The assessment of the AMAP, ${ }^{1}$ noted that the freshwater content in the Arctic Ocean has increased in recent years compared with the average for $1980-2000$ by 8,000 cubic kilometers, or by more than $11 \%$. If this volume left the Arctic Ocean, it would affect circulation in the North Atlantic. However, earlier Polyakov ${ }^{2}$ shown that during the twentieth century the Arctic basin became more and more salty with the loss of fresh water of $239-270 \mathrm{~km}^{3}$ per decade. In the perennial series of freshwater content, two periods stand out in the $1920 \mathrm{~s}$ 1930s and in recent decades, when the Arctic basin was more saline, despite an increase in the inflow of river water and precipitation, and two periods at the beginning of the century and in the 1940-70s when he was more freshened. The authors explain this discrepancy by the increased removal of ice and fresh water under the influence of the wind. They also note that changes in the influx of Atlantic water did not have a noticeable effect on changes in water masses in the upper layer. The freshwater budget of the Arctic Ocean is formed with the participation of the global hydrological cycle and with it responds to global climate change. Atmospheric moisture transport from low latitudes, river runoff from the surrounding land and reverse sea transport of fresh water are the main components of the freshwater budget of the Arctic Ocean. Freshwater entering the Arctic with the polar branch of the global hydrological cycle accumulates in the upper layer of the ocean and prevents it from mixing with the underlying waters. This circumstance, together with the strong cooling of the layer during the winter period, ensures the preservation of drifting ice on its surface currently. Water from the upper layer is carried in the liquid and solid (sea ice) phases to the North Atlantic. This process controls the spread of the desalinated water and sea ice on the surface of the North Atlantic and constitutes the main link in the formation of the Arctic impact on the global climate.
Volume 3 Issue 2 - 2019

\author{
Alekseev Genrikh, Glok Natalia,Vyazilova \\ Anastasia \\ Arctic and Antarctic Research Institute, St. Petersburg, Russia
}

Correspondence: Alekseev Genrikh, Arctic and Antarctic Research Institute, St. Petersburg, Russia, Email alexgv@aari.ru

Received: March 02, 2019 | Published: March 13, 2019

Fresh water entering the Arctic Ocean undergoes multiple "water-ice" phase transformations that will change the dynamic and thermodynamic properties of the upper ocean layer and the residence time of incoming fresh water and thereby affect the formation of freshwater outflow. These processes constitute a kind of internal arctic hydrological cycle, acting together with the external cycle, which constitute the processes of fresh water influx into the Arctic Ocean and further to the North Atlantic. Most model and empirical calculations give an estimate close to the equal contribution of both components in the resulting freshwater flow from the Arctic Ocean. To estimate the content of fresh water, it should be calculated relative to some a priori given salinity. Aagaard \& Carmack $^{3}$ suggested a salinity of $34.80 \mathrm{psu}$ as such reference salinity. This choice has a deep physical meaning, since this value is close to the critical value of salinity (approximately $34.80 \mathrm{psu}$ ), ${ }^{4}$ which separates the modes of deep and shallow convection in the central part of the Greenland Sea where water structure below the upper layer is close to the structure in the Arctic Basin. When the salinity of water in the upper layer is close to the critical value, the low-temperature compressibility of seawater operates, ensuring the convection plumes fall to great depths ${ }^{3}$. From this point of view, after removal of an excess fresh water from upper layer with a salinity of less than 34.80 psu will become possible deep convective mixing and, therefore, ice-free regime in the Arctic Ocean.

To calculate the excess fresh water in the upper layer from the surface to the depth of isochaline 34.80 used data from 8 winterspring surveys of the Arctic Ocean by the Soviet expeditions "North" in 1955-1979. The average for 1955-1979 distribution of freshwater content (FWC) in layer above the the 34.80 isohalin show a maximum in the Beaufort sea gyre and a gradual decrease towards the Barents Sea and the Fram Strait. The maximum value of the FWC is formed by the joint contribution of strong desalination in the upper 30-50 meter layer and the influx of Pacific waters, the influence of which is noticeable here to a great depth. The layer in which the fresh water content was estimated has a thickness of from $120 \mathrm{~m}$ in the Atlantic part of the Arctic basin to $800 \mathrm{~m}$ above the Canadian Basin. The distribution of FWC in the vertical is also non-uniform in these parts of the Arctic Ocean: in the near-Atlantic part, its main part $(60 \%)$ is in the upper $50 \mathrm{~m}$ layer, and above the Canadian hollow in this layer is only $40 \%$ of the total fresh water. In general, the greatest amount of fresh water is concentrated in this area under the influence 
of anticyclonic circulation, and desalination here penetrates to a depth of $800 \mathrm{~m}$, which is apparently due to its descent in the center of the anticyclonic circulation. ${ }^{6,7}$

In connection with significant fluctuations from year to year of salinity and, accordingly, the content of fresh water in the upper layer of the Arctic Ocean, the question arises about their cause. The time series of components of the external inflows of fresh water into the Arctic Ocean ${ }^{8,9}$ show a certain increase in precipitation and runoff of rivers in the Arctic Ocean in the first half of the 1960s. However, correlations of these changes with fluctuations in salinity in various regions of the Arctic Ocean and the North Seas are weak. ${ }^{10}$

Calculations of freshwater budget components show ${ }^{5}$ that the bulk of fresh water enters the Arctic Ocean in summer. The total inflow during the summer period is estimated from 6,000 to 10,000 $\mathrm{km}^{3}$, which is much more than the average inflow over the year. ${ }^{5}$ The discrepancy is eliminated during the winter by converting a significant portion of fresh water into sea ice. However, changes in the conditions of summer melting and winter ice formation can lead to an imbalance in the freeze-melting cycle and, accordingly, to desalination or salinization of the upper layer in some years. In the winter period (from October to May), the bulk of fresh water from summer melting freezes out, mainly due to the formation of young ice, which for the most part is compressed during intensive movements of drifting ice. Measurements of the growth of perennial ices in winter, together with estimates of salinization of the upper layer, show that the freezing of fresh water is more associated with the growth of young ice than with the increase in the thickness of old ice.

The most striking result of the increase in freshwater outflow from the Arctic Ocean was a strong desalination in the upper layer of the North Atlantic in 1963-1973, called the great salinity anomaly. ${ }^{11}$ All researchers who have examined this phenomenon point to the origins of the anomaly in the Arctic Ocean. ${ }^{12,13}$ The first manifestation of the anomaly in the 1960s was found in a decrease in the salinity of water in the upper water layer north of Iceland ${ }^{14}$ in the summer of 1963. The greatest decrease in salinity on the horizon of $50 \mathrm{~m}$ was noted here in $1969 .{ }^{15}$ At the same time, according to the data of Drinkwater, ${ }^{16}$ the lowest values of salinity and water temperature were noted off the west coast of Greenland in the Fylla Bank area in the area of the West Greenland Current. This circumstance indicates the almost simultaneous development of desalination in both regions and the two routes of fresh water from the Arctic to the North Atlantic: through the Fram and Danish Straits in the east and through the Baffin Sea and Davis Strait in the west. The source of the anomalous desalination of the upper layer of the Arctic Ocean in the 1960s could be a strong summer melting of ice and snow in the Arctic Ocean and on the surface of the Arctic land. In the summer of 1957-1962 in the Arctic unusually high air temperatures were observed, especially in the region of Western Greenland, the Baffin Sea and the adjacent part of the Canadian Archipelago, where the greatest amount of snow and ice accumulates in winter. ${ }^{17}$ Large positive air temperature anomalies here contributed to intensive summer thawing and freshwater flow into the Arctic Ocean, the Canadian Straits, the Baffin Sea and Hudson Bay.

Concerning the causes and contribution of various factors to the increase in summer warming, research results are differed. Dufour ${ }^{18}$ considers that the summer atmospheric moisture inflow from low latitudes dominates in the seasonal cycle and find the weakening

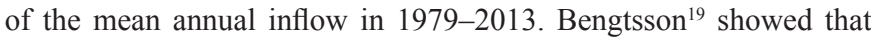
precipitation and horizontal moisture transfer to the Arctic (north of $60^{\circ}$.N.) is maximum in August and September, and evaporation in
June and July. Serreze ${ }^{20}$ found the largest increase in moisture content in the atmosphere of the Arctic in the summer and early autumn. Dufour ${ }^{18}$ sees this as an argument against increasing the influx of water vapor into the Arctic from outside with climate warming in favor of increasing the role of evaporation. Sejas ${ }^{21}$ believes that less warming compared to winter in summer is associated with the opposite nature of feedback between shortwave and longwave radiation with cloudiness and albedo and with the influx of heat into the ocean. In autumn and winter, the ocean gives off summer heat, which, together with positive feedback of long-wave radiation and cloudiness, increases warming. The recent publications are noted that the Arctic freshwater content has increased significantly over the last two decades, with potential future implications for the Atlantic meridional overturning circulation downstream. ${ }^{22}$ The liquid freshwater content significantly increased also in the Beaufort Gyre in the 2000s during an anticyclonic wind regime and remained at a high level despite a transition to a more cyclonic state ${ }^{23}$ in the early 2010s. Since the high-latitude freshwater plays a crucial role in establishing and regulating global thermohaline circulation, the long-term variations of the freshwater content should be considered when assessing climate change and variability. ${ }^{2}$

\section{Acknowledgments}

The paper is sponsored by Russian Foundation for Basic Research with grant number 18-05-60107.

\section{Conflicts of interest}

The author declares that there is no conflict of interest.

\section{References}

1. Arctic Monitoring and Assessment Programme (AMAP). Snow, Water, Ice and Permafrost in the Arctic. Oslo Norway. 2017. 269 p.

2. Polyakov IV, Alexeev V, Belchansky GI, et al. Arctic Ocean freshwater changes over the past 100 years and their causes. Journal of Climate. 2008;21:364-384.

3. Aagaard KA, Carmack EC. The role of sea ice and other freshwater in the Arctic circulation. Journal of Geophysical Research. 1989;94(C10):14485-14498.

4. Alekseev GV, Ivanov VV, Korablev AA. Interannual variability of deep convection in the Greenland Sea. Okeanologiya. 1995;35(1):45-52.

5. Alekseev GV, Bulatov LV, Zakharov VF. Freshwater melting/freezing cycle in the Arctic Ocean. In: Lewis EW, editor. The Freshwater Budget of the Arctic Ocean. NATO Science Series. Kluwer Academic Publishers. 2000;589-608

6. Treshnikov AF, Baranov GI. Water circulation structure in the Arctic Basin. Leningrad: Gidrometeoizdat. 1972.

7. Proshutinsky AY, Johnson MA. Two circulation regimes of wind-driven Arctic Ocean. Journal of Geophysical Research. 1997;102(C6):1249312514.

8. Shiklomanov I, Shiklomanov A, Lammers R. The dynamics of river water inflow to the Arctic Ocean. In: Lewis EW, Editor. The Freshwater Budget of the Arctic Ocean. Dordrecht: Kluwer Academic Publishers. 1999;281-286.

9. Walsh J. Global atmospheric circulation patterns and their effect on AFW fluxes. In: Lewis EW, Editor. The Freshwater Budget of the Arctic Ocean. Dordrecht: Kluwer Academic Publishers. 1999.

10. Alekseev GV, Makshtas AP. Study of processes of ocean/atmosphere interaction in the Arctic Basin. Problems of the Arctic and Antarctic. 1998; 71:15-25. 
11. Dickson RR, Meincke J, Malmberg SA, et al. The "Great Salinity Anomaly" in the Northern North Atlantic 1968-1982. Prog Oceanog. 1988;20(2):103-151

12. Mysak LA, Manak DK, Marsden RF. Sea ice anomalies observed in the Greenland and Labrador Seas during 1901-1984 and their relation to an interdecadel Arctic climate cycle. Climate Dynamics. 1990;5(2):111132.

13. Hakkinen S. An Arctic Source for the Great Salinity Anomaly: A simulation of the Arctic ice-ocean system for 1955-1975. Journal of Geophysical Research. 1993;98(C9):16397-16410.

14. Steffansson U. Temperature variations in the North Icelandic coastal area during recent decades. Jokull. 1969;19:18-28.

15. Malmberg SA, Blindheim J. Climate, cod, and capelin in northern waters. ICES Marine Science Symposia. 1994;198:297-310.

16. Drinkwater KF. Climate and oceanographic variability in the Northwest Atlantic during 1980s and early 1990s. NAFO SCR Doc. 94/71. 1994;139.

17. Kotlyakov VM. Atlas of snow and ice resources of the world. Moskow: Russian Academy of Sciences. 1997;342.
18. Dufour A, Zolina O, Gulev SK. Atmospheric moisture transport to the Arctic: Assessment of reanalyses and analysis of transport components. Journal of Climate. 2016;29(14):5061-5081.

19. Bengtsson L, Hodges KI, Koumoutsaris S, et al. The changing atmospheric water cycle in Polar Regions in a warmer climate. Tellus $A$. 2011;63(5):907-920.

20. Serreze MC, Barrett AP, Stroeve J. Recent changes in tropospheric water vapor over the Arctic as assessed from radiosondes and atmospheric reanalyses. Journal of Geophysical Research: Atmospheres. 2012;117(D10).

21. Sejas SA, Cai M, Hu A, et al. Individual feedback contributions to the seasonality of surface warming. Journal of Climate. 2014;27(14):56535669.

22. Johnson HL, Cornish SB, Kostov Y, et al. Arctic ocean freshwater content and its decadal memory of sea-level pressure. Geophysical Research Letters. 2018;45(10):4991-5001.

23. Wang Q, Wekerle C, Danilov S, et al. Arctic Sea Ice Decline Significantly Contributed to the Unprecedented Liquid Freshwater Accumulation in the Beaufort Gyre of the Arctic Ocean. Geophysical Research Letters. 2018;45(10):4956-4964. 